\section{UK researchers call for limits on animal experiment 'red tape'}

\section{Natasha Loder, London}

More than 100 leading UK medical researchers have written to British science minister David Sainsbury to ask for an end to what they claim are excessive delays and red tape involved in regulating animal experimentation.

The researchers, who include five winners of the Nobel Prize for Medicine and 38 Fellows of the Royal Society, say they are worried that Britain could lose its leading position in biomedical science.

"It can now take six months or longer to obtain approval for a research project using animals in the UK, whilst in other countries it can take weeks or even days," the authors of the letter write. They emphasize that animal studies are likely to increase in importance once the human genome sequence is completed.

They also report that some researchers are now taking their work abroad in response to the British situation. One researcher says that he now does some of his work in the United States because of the "tardiness of the Home Office in issuing appropriate licenses".

One of the signatories to the letter is Nancy Rothwell, professor of physiology at the University of Manchester. She is also a member of the UK Life Sciences Committee (UKLSC), which promotes the interests of a number of scientific societies. Rothwell says that the UKLSC is keen to start a dialogue with the Home Office to see how the current situation might be improved. But there will be no simple answer, she says.

Bob Combes, scientific director of the Fund for the Replacement of Animals in Medical Experiments, says: "If there is good science being done and it has to be done with animals then sooner done the better. We fully support the removal of unnecessary bureaucracy, but the question is: what is [unnecessary]?"

Combes says that many scientists see the checks and balances in the current regulations as bureaucratic. "But we see them as necessary. Unfortunately, not all scientists appreciate that animal welfare should be inextricably linked to best scientific practice."

Many of the UKLSC's member societies feel that the UK government has done little to listen to their worries over the regulations. But Sainsbury said this week that he would look into the scientists' concerns, and has agreed to meet with a representative delegation of the letter's signatories.

\title{
US climate report underlines local impacts of warming
}

Paul Smaglik, Washington

Americans are finding out this week how radically a change in climate could affect their lives. The US Global Change Research Program (GCRP) has issued a draft report outlining some of the dramatic effects global warming could have on the country.

If, the report predicts, the average temperature of the United States rises by five to ten degrees Fahrenheit over the next 100 years, the Great Lakes and the southwestern desert would shrink significantly, and rates of thawing would increase in Alaska.

The GCRP was set up by Congress in 1990, and brings together the efforts of ten federal departments and agencies, as well as outside organizations. The report has been under preparation since 1997, when it was started by a series of 20 workshops held around the country to identify the critical interfaces between climate change, the environment, and society.

Its draft conclusions focus on the probable consequences of global warming, rather than on how this will occur. But that approach, while dramatizing the potential impact, opens the conclusions to criticism, as regional climate modelling is on less firm scientific ground than global modelling.

Michael MacCracken, director of the National Assessment Coordination Office of the GCRP, says that the projections are all "plausible" and are scored by likelihood, based on the best available computer modelling. But they include some 'wiggle room'. For example, the Southeast will become either hot and dry or warm and moist - but not hot and moist. The report stresses that, given the complexity of the environment and its interaction with climate, both surprises and uncertainties are likely.

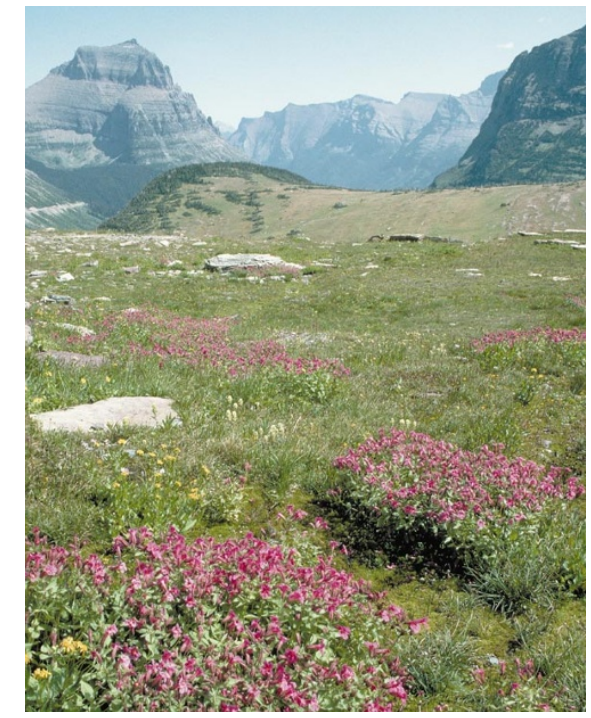

Rocky future? Global warming could mean bad news for alpine meadows.

Environmental groups have applauded the report for pointing out that natural ecosystems, such as alpine meadows in the Rocky Mountains, could be especially vulnerable to global warming. "The assessment shows that many of the country's distinct natural features could deteriorate as a result of changing climate," says Susan Subak, a senior research associate at the Natural Resources Defense Council.

Industry groups are less pleased. "We're troubled by the pessimistic nature of some of the things that it says, especially when the computer models are very contradictory," says Frank Maisano, spokesman for the Global Climate Coalition. Maisano notes that regional predictions of climate change are unreliable. - http://www.gcrio.org/NationalAssessment/sgsr.html

\section{Los Alamos 'loses' key weapons data}

\section{Rex Dalton, San Diego}

The Los Alamos National Laboratory in New Mexico is facing new embarrassment over its security procedures this week, after admitting that it has lost computer hard drives containing classified information about the design of nuclear weapons.

The drives were found to be missing when the laboratory was being cleared of important equipment as brush fires approached last month (see Nature 405, $264 ; 2000)$. "This is an extremely serious matter and we are taking swift actions to deal with it," laboratory director John Browne said on Monday.
The laboratory is run by the University of California on behalf of the Department of Energy. Browne said that a joint investigation is being carried out by the department and the Federal Bureau of Investigation. He has promised "appropriate disciplinary actions" if individuals are found to be responsible.

The missing data are believed to include information about how to defuse nuclear devices in case of emergencies, as well as data on Russian weapons. A statement from the laboratory said that efforts were continuing to locate the missing media "or to determine if they were inadvertently destroyed". 